\title{
Reactions of Cyclotetradeca-1,8-diyne with Triosmium Carbonyl Clusters
}

\author{
Wen-Yann Yeh* and Ming-Ann Hsu \\ Department of Chemistry, National Sun Yat-Sen University, Kaohsiung, Taiwan 804 \\ Shie-Ming Peng ${ }^{\dagger}$ and Gene-Hsiang Lee \\ Department of Chemistry, National Taiwan University, Taipei, Taiwan 106
}

Received November 2, 1998

\begin{abstract}
Reaction of $\mathrm{Os}_{3}(\mathrm{CO})_{10}(\mathrm{NCMe})_{2}$ and cyclotetradeca-1,8-diyne $\left(\mathrm{C}_{14} \mathrm{H}_{20}\right)$ affords the alkyne complexes $\mathrm{Os}_{3}(\mathrm{CO})_{10}\left(\mu_{3}-\eta^{2}-\mathrm{C}_{14} \mathrm{H}_{20}\right)$ (1) and $\left(\mathrm{Os}_{3}(\mathrm{CO})_{10}\right)_{2}\left(\mu_{3}, \mu_{3}-\eta^{2}, \eta^{2}-\mathrm{C}_{14} \mathrm{H}_{20}\right)$ (2). Thermolysis of 1 results in a $\mathrm{C}-\mathrm{H}$ bond activation to give the hydrido allene complex $(\mu-\mathrm{H}) \mathrm{Os}_{3}(\mathrm{CO})_{9}\left(\mu_{3^{-}}\right.$ $\eta^{3}-\mathrm{C}_{14} \mathrm{H}_{19}$ ) (3). Photoirradiation of $\mathbf{I}$ in the presence of $\mathrm{C}_{14} \mathrm{H}_{20}$ ligand produces the metallacyclopentadienyl complex $\mathrm{Os}_{3}(\mathrm{CO})_{9}\left(\mu-\eta^{4}-\mathrm{C}_{4}\left(\mathrm{C}_{12} \mathrm{H}_{20}\right)_{2}\right)(\mathbf{4})$. In contrast, $\mathrm{Fe}_{3}(\mathrm{CO})_{12}$ reacts with $\mathrm{C}_{14} \mathrm{H}_{20}$ to generate $\mathrm{Fe}_{3}(\mathrm{CO})_{9}\left(\mu_{3}-\eta^{2}-\mathrm{C}_{14} \mathrm{H}_{20}\right)$ (5), which upon heating undergoes cluster fragmentation to give the known complexes $\left(\eta^{4}-\mathrm{C}_{4}\left(\mathrm{C}_{10} \mathrm{H}_{20}\right)\right) \mathrm{Fe}(\mathrm{CO})_{3}$ and $\left[\left(\eta^{5}-\mathrm{C}_{5}\left(\mathrm{C}_{9} \mathrm{H}_{18}\right)\right) \mathrm{Fe}\right.$ $\left.(\mathrm{CO})_{2}\right]_{2}$. The new compounds $\mathbf{1}-\mathbf{5}$ have been characterized by mass, IR, and NMR spectroscopy. The structures of $\mathbf{2}-\mathbf{4}$ have been determined by an X-ray diffraction study.
\end{abstract}

\section{Introduction}

Cycloalkadiynes ${ }^{1}$ are versatile starting materials for synthesis of superphanes and cage compounds, ${ }^{2}$ which have grown to be an important discipline that is attracting both synthetic and physical chemists. For instance, several metal-capped cyclobutadienophane and cyclobutadienosuperphane complexes were prepared by Gleiter and co-workers from the reactions of cycloalkadiynes with $\mathrm{Fe}(\mathrm{CO})_{5}, \mathrm{CpCo}(\mathrm{CO})_{2}$, and $\mathrm{Cp} * \mathrm{Co}-$ $\left(\mathrm{C}_{2} \mathrm{H}_{4}\right)_{2}$, through a metal-mediated intra- or intermolecular alkyne-alkyne coupling process. ${ }^{3}$ H owever, the coordination chemistry of cyclodiynes with transitionmetal clusters has received little attention. Our continuing interest in alkyne-cluster complexes ${ }^{4}$ ther efore prompted us to investigate the reaction of cyclotetradeca-1,8-diyne with triosmium carbonyl clusters.

† To whom inquiries concerning the X-ray crystallographic work should be addressed.

(1) (a) Nakagawa, M. In Topics in Nonbenzenoid Aromatic Chemistry; Hirokawa: Tokyo, 1973: Vol. 1. (b) Sondheimer, F. Acc. Chem Res. 1972, 5, 81. (c) Gleiter, R. Angew. Chem., Int. Ed. Engl. 1992, 31, 27. (d) Gleiter, R.; Karcher, M.; J ahn, R.; Irngartinger, H. Chem. Ber. 1988, 121, 735. (e) Gleiter, R.; Schäfer, W. Acc. Chem. Res. 1990, 23, 369.

(2) (a) Vögtle, F. Cyclophane Chemistry: Synthesis, Structures and Reactivity; Wiley: Chichester, U.K., 1993. (b) Cram, D. J .; Cram, J M. Container Molecules and Their Guests; The Royal Society of Chemistry: London, 1994. (c) Gleiter, R.; Merger, M. Angew. Chem., Int. Ed. Engl. 1997, 36, 2426. (d) Kloster-J ensen, E.; Wirz, J . Angew. Chem., Int. Ed. Engl. 1973, 12, 671. (e) Gladysz, J . A.; Fulcher, J . G.; Lee, S. J .; Bocarsley, A. B. Tetrahedron Lett. 1977, 3421. (f) King, R. B.; Efraty, A. J . Am. Chem. Soc. 1970, 92, 6071; 1972, 94, 3021. (g) King, R. B.; Ackermann, M. N. J . Organomet. Chem. 1974, 67, 431. (h) Mehta, G.; Viswanath, B.; Sastry, N.; J emmis, E. D.; Sivakumar D.; Reddy, K.; Kunwar, A. C. Angew. Chem., Int. Ed. Engl. 1992, 31, 1488. (i) Adams, C. M.; Holt, E. M. Organometallics 1990, 9, 980.

(3) (a) Gleiter, R.; Stahr, H.; Nuber, B. Organometallics 1997, 16 646. (b) Gleiter, R.; Merger, M. Oeser, T.; Irngartinger, H. Tetrahedron Lett. 1995, 36, 4625. (c) Gleiter, R.; Langer, H.; Schehlmann, V.; Nuber, B. Organometallics 1995, 14, 975. (d) Gleiter, R.; Langer, H.; Nuber, B. Angew. Chem., Int. Ed. Engl. 1994, 33, 1272. (e) Gleiter, R. Pflästerer, G.; Nuber, B. J . Chem. Soc., Chem. Commun. 1993, 454 (f) Gleiter, R.; Pflästerer, G. Organometallics 1993, 12, 1886. (g) Gleiter, R.; Schehlmann, V. Angew. Chem., Int. Ed. Engl. 1990, 29, 1426.

\section{Experimental Section}

General Methods. All manipulations were carried out under an atmosphere of purified dinitrogen with standard Schlenk techniques. ${ }^{5} \mathrm{Os}_{3}(\mathrm{CO})_{12}$ was prepared from $\mathrm{OsO}_{4}$ and $\mathrm{CO}$ as described in the literature. ${ }^{6}$ Cyclotetradeca-1,8-diyne $\left(\mathrm{C}_{14} \mathrm{H}_{20}\right)^{7}$ and $\mathrm{Os}_{3}(\mathrm{CO})_{10}(\mathrm{NCMe})_{2}^{8}$ were prepared by literature methods. $\mathrm{Fe}_{3}(\mathrm{CO})_{12}$ from Strem was used as received. Solvents were dried over appropriate reagents under dinitrogen and distilled immediately before use. Preparative thin-layer chromatographic (TLC) plates were prepared from silica gel (Merck). Infrared spectra were recorded with a $0.1 \mathrm{~mm}$ pathlength $\mathrm{CaF}_{2}$ solution cell on a Hitachi I-2001 IR spectrometer. ${ }^{1} \mathrm{H}$ and ${ }^{13} \mathrm{C}$ NMR spectra were obtained on a Varian VXR-300 spectrometer at 300 and $75.4 \mathrm{MHz}$, respectively. Fast-atom-bombardment ( $\mathrm{FAB}$ ) mass spectra were recorded by using a VG Blotch-5022 mass spectrometer. Elemental analyses were performed at the National Science Council Regional Instrumentation Center at National Chen-Kung University, Tainan, Taiwan.

Reaction of $\mathbf{C}_{14} \mathbf{H}_{20}$ and $\mathbf{O s}_{3}(\mathbf{C O})_{10}(\mathbf{N C M e})_{2} \cdot \mathrm{C}_{14} \mathrm{H}_{20}(46$ $\mathrm{mg}, 0.246 \mathrm{mmol}), \mathrm{Os}_{3}(\mathrm{CO})_{10}(\mathrm{NCMe})_{2}(106 \mathrm{mg}, 0.113 \mathrm{mmol})$, and benzene $(50 \mathrm{~mL})$ were introduced into a $100 \mathrm{~mL}$ Schlenk flask under a dinitrogen atmosphere. The flask was placed in an oil bath at $65-70{ }^{\circ} \mathrm{C}$ for $15 \mathrm{~min}$, resulting in a color change from yellow to orange-red. The solution was cooled to room temperature, and the yellow precipitate was filtered. The filtrate was concentrated to ca. $2 \mathrm{~mL}$ on a rotary evaporator and subjected to TLC, with petroleum ether as eluent. Isolation of the materials forming the major orange band afforded $\mathrm{Os}_{3-}$ $(\mathrm{CO})_{10}\left(\mu_{3}-\eta^{2}-\mathrm{C}_{14} \mathrm{H}_{20}\right)(\mathbf{1} ; 101 \mathrm{mg}, 86 \%)$.

(4) (a) Yeh, W.-Y. Hsu, S. C. N.; Peng, S.-M.; Lee, G.-H. Organo metallics 1998, 17, 2477. (b) Yeh, W.-Y.; Ho, C.-L.; Chiang, M. Y.; Chen, I.-T. Organometallics 1997, 16, 2698. (c) Yeh, W.-Y.; Chen, S.-L.; Peng, S.-M.; Lee, G.-H. J . Organomet. Chem. 1993, 461, 207.

(5) Shriver, D. F : Drezdzon, M. A. TheManipulation of Air-Sensitive Compounds, 2nd ed.; Wiley: New York, 1986.

(6) J ohnson, B. F. G.; Lewis, J . Inorg. Synth. 1972, 13, 92.

(7) Gleiter, R.; Merger, R.; Treptow, B.; Wittwer, W.; Pflästerer, G. Synthesis 1993, 558.

(8) Braga, D.; Grepioni, F.; Parisini, E.; J ohnson, B. F. G.; Martin, C. M.; Nairn, J . G. M.; Lewis, J .; Martinelli, M. J . Chem. Soc., Dalton Trans. 1993, 1891 
The yellow precipitate was extracted with hot THF $(10 \mathrm{~mL})$ and filtered. The filtrate was then concentrated to ca. $2 \mathrm{~mL}$, layered with $\mathrm{n}$-hexane $(10 \mathrm{~mL})$, and placed in a freezer at -15 ${ }^{\circ} \mathrm{C}$ overnight, yielding orange-yel low needle crystals of $\left(\mathrm{Os}_{3}-\right.$ $\left.(\mathrm{CO})_{10}\right)_{2}\left(\mu_{3}, \mu_{3}-\eta^{2}, \eta^{2}-\mathrm{C}_{14} \mathrm{H}_{20}\right)(2 ; 12 \mathrm{mg}, 11 \%)$.

Characterization of 1. Mass spectrum (FAB): m/z 1044 ( $\left.\mathrm{M}^{+},{ }^{192} \mathrm{Os}\right), 1044-28 \mathrm{n}(\mathrm{n}=1-10) . \mathrm{IR}$ ( $\mathrm{n}$-hexane, $\left.v(\mathrm{CO})\right): 2104$ (w), 2060 (vs), 2048 (sh), 2020 (s), 2000 (m), 1994 (m), 1982 (w), $1850(\mathrm{w}) \mathrm{cm}^{-1} .{ }^{1} \mathrm{H} \mathrm{NMR}\left(\mathrm{CDCl}_{3}, 23{ }^{\circ} \mathrm{C}\right): \delta 2.46(\mathrm{~m}, 4 \mathrm{H})$, $2.14(\mathrm{~m}, 4 \mathrm{H}), 2.02(\mathrm{~m}, 4 \mathrm{H}), 1.45(\mathrm{~m}, 4 \mathrm{H}), 1.23(\mathrm{~m}, 2 \mathrm{H}) .{ }^{13} \mathrm{C}-$ $\left\{{ }^{1} \mathrm{H}\right\} \mathrm{NMR}\left(\mathrm{CDCl}_{3}, 23^{\circ} \mathrm{C}\right): \delta 148.4(\mathrm{C} \equiv \mathrm{C}-\mathrm{Os}), 80.7(\mathrm{C} \equiv \mathrm{C})$, 50.7, 33.5, 28.9, 26.8, $18.3\left(\mathrm{CH}_{2}\right)$. Anal. Calcd for $\mathrm{C}_{24} \mathrm{H}_{20} \mathrm{O}_{10^{-}}$ Oss: C, 27.74; H, 1.94. Found: C, 27.78; H, 2.06.

Characterization of 2. Mass spectrum (FAB): m/z 1900 $\left(\mathrm{M}^{+},{ }^{192} \mathrm{Os}\right)$. IR (THF, v(CO)): 2100 (w), 2060 (vs), 2044 (s), 2016 (s), 2000 (s), 1992 (m), 1980 (sh), 1964 (w), 1854 (vw) $\mathrm{cm}^{-1}$. IR (KBr disk, $\left.v(\mathrm{CO})\right): 2104(\mathrm{~m}), 2046(\mathrm{~s}, \mathrm{br}), 2000(\mathrm{~s}$, br), 1986 (s, br), $1950(\mathrm{~m}), 1840(\mathrm{~m}) \mathrm{cm}^{-1} .{ }^{1} \mathrm{H}$ NMR (THF- $\mathrm{d}_{8}$, $\left.23{ }^{\circ} \mathrm{C}\right): \delta 3.20(\mathrm{~m}, 8 \mathrm{H}), 2.09(\mathrm{~m}, 8 \mathrm{H}), 1.88(\mathrm{~m}, 4 \mathrm{H}) .{ }^{13} \mathrm{C}\left\{{ }^{1} \mathrm{H}\right\}$ NMR $\left(\mathrm{CDCl}_{2}, 23{ }^{\circ} \mathrm{C}\right): \delta 150.0(\mathrm{C} \equiv \mathrm{C}-\mathrm{Os}), 50.6,42.2,34.0$ $\left(\mathrm{CH}_{2}\right)$. Anal. Calcd for $\mathrm{C}_{34} \mathrm{H}_{20} \mathrm{O}_{20} \mathrm{Os}_{6}$ : C, 21.61; $\mathrm{H}, 1.06$. Found: C, 21.68; $\mathrm{H}, 1.12$.

Reaction of 1 with $\mathrm{Os}_{3}(\mathrm{CO})_{10}(\mathrm{NCMe})_{2}$. $\mathrm{Os}_{3}(\mathrm{CO})_{10}\left(\mu_{3}-\eta^{2}\right.$ $\left.\mathrm{C}_{14} \mathrm{H}_{20}\right)(\mathbf{1} ; 11 \mathrm{mg}, 0.01 \mathrm{mmol})$ and $\mathrm{Os}_{3}(\mathrm{CO})_{10}(\mathrm{NCMe})_{2}(20 \mathrm{mg}$ $0.02 \mathrm{mmol})$ were dissolved in benzene $(10 \mathrm{~mL})$ under a dinitrogen atmosphere. The solution was heated at $65-70{ }^{\circ} \mathrm{C}$ for $15 \mathrm{~min}$, yiel ding a yellow precipitate. The precipitate was collected by filtration, washed with benzene, and crystallized from THF/n-hexane at $-15{ }^{\circ} \mathrm{C}$ to give $\left(\mathrm{Os}_{3}(\mathrm{CO})_{10}\right)_{2}\left(\mu_{3}, \mu_{3}-\eta^{2}, \eta^{2}-\right.$ $\left.\mathrm{C}_{14} \mathrm{H}_{20}\right)(2 ; 10 \mathrm{mg}, 53 \%)$.

Thermolysis of $1 . \mathrm{Os}_{3}(\mathrm{CO})_{10}\left(\mu_{3}-\eta^{2}-\mathrm{C}_{14} \mathrm{H}_{20}\right)(\mathbf{1} ; 156 \mathrm{mg}, 0.15$ $\mathrm{mmol})$ dissolved in $\mathrm{n}$-heptane $(50 \mathrm{~mL})$ was heated to reflux $\left(98^{\circ} \mathrm{C}\right.$ ) under dinitrogen for $1 \mathrm{~h}$. During the reaction, the solution changed from orange to light yellow. The solvent was removed under vacuum, and the residue was subjected to TLC, with $\mathrm{CH}_{2} \mathrm{Cl}_{2} / \mathrm{n}$-hexane as eluent $(1: 9, \mathrm{v} / \mathrm{v}) .(\mu-\mathrm{H}) \mathrm{Os}_{3}(\mathrm{CO})_{9}\left(\mu_{3^{-}}\right.$ $\left.\eta^{3}-\mathrm{C}_{14} \mathrm{H}_{19}\right)(3 ; 137 \mathrm{mg}, 90 \%)$ was isolated from the major yellow band. Mass spectrum (FAB): $\mathrm{m} / \mathrm{z} 1016$ (M+, $\left.{ }^{+192} \mathrm{Os}\right), 1016-28 \mathrm{n}$ $(\mathrm{n}=1-9)$. IR $\left(\mathrm{C}_{6} \mathrm{H}_{12}, v(\mathrm{CO})\right): 2099(\mathrm{~m}), 2069$ (s), 2041 (s), 2019 (s), 2004 (m), 1993 (s), 1987 (m), 1982 (w), 1975 (w) cm ${ }^{-1} .{ }^{1} \mathrm{H}$ $\operatorname{NMR}\left(\mathrm{C}_{6} \mathrm{D}_{6}, 23{ }^{\circ} \mathrm{C}\right): \delta 2.86-0.86(\mathrm{~m}, 19 \mathrm{H}),-22.03(\mathrm{~s}, \mu-\mathrm{H})$. ${ }^{13} \mathrm{C}\left\{{ }^{1} \mathrm{H}\right\} \mathrm{NMR}\left(\mathrm{C}_{6} \mathrm{D}_{6}, 23^{\circ} \mathrm{C}\right): \delta 176.9(\mathrm{CO}), 175.7(\mathrm{C}=\mathrm{C}=\mathrm{CH})$, 173.9 (CO), 173.9 (CO), 170.7 (CO), 170.4 (CO), 167.1 (CO), $162.1(\mathrm{C}=\mathrm{C}=\mathrm{CH}), 125.0(\mathrm{C}=\mathrm{C}=\mathrm{CH}), 81.1,80.2(\mathrm{C} \equiv \mathrm{C}), 48.7$, 40.7, 34.4, 31.2, 29.3, 28.4, 26.1, 19.0, $17.9\left(\mathrm{CH}_{2}\right)$. Anal. Calcd for $\mathrm{C}_{23} \mathrm{H}_{20} \mathrm{O}_{9} \mathrm{Os}_{3}$ : C, 27.33; $\mathrm{H}, 1.98$. Found: $\mathrm{C}, 27.30 ; \mathrm{H}, 1.88$.

Photoirradiation of $\mathbf{I}$ in the Presence of $\mathrm{C}_{14} \mathrm{H}_{20}$. This reaction was carried out in an ACE microscale photoreaction vessel equipped with an immersed Pen-Ray $5.5 \mathrm{~W}$ lowpressure, cold-cathode, mercury gaseous discharge lamp. $\mathrm{Os}_{3^{-}}$ $(\mathrm{CO})_{10}\left(\mu_{3}-\eta^{2}-\mathrm{C}_{14} \mathrm{H}_{20}\right)(\mathbf{1} ; 50 \mathrm{mg}, 0.048 \mathrm{mmol}), \mathrm{C}_{14} \mathrm{H}_{20}(40 \mathrm{mg}$, $0.213 \mathrm{mmol})$, and $\mathrm{n}$-hexane $(50 \mathrm{~mL}$ ) were introduced into the reaction vessel under an atmosphere of dinitrogen. The mixture was irradiated for $1.5 \mathrm{~h}$ with dinitrogen slowly bubbling through the solution. During the reaction, the solution changed gradually from orange to gray-yellow. The solvent was removed on a rotary evaporator, and the residue was subjected to TLC, with $\mathrm{CH}_{2} \mathrm{Cl}_{2} / \mathrm{n}$-hexane as eluent (1:9, v/v). Compound 1 ( $24 \mathrm{mg}, 48 \%$ ) was recovered from the first orange band. The major purple-gray band yielded $\mathrm{Os}_{3}(\mathrm{CO})_{9}\left(\mu-\eta^{4}-\mathrm{C}_{4}{ }^{-}\right.$ $\left.\left(\mathrm{C}_{12} \mathrm{H}_{20}\right)_{2}\right)(4 ; 28 \mathrm{mg}, 48 \%)$. Mass spectrum (FAB): $\mathrm{m} / \mathrm{z} 1204$ $\left(\mathrm{M}^{+},{ }_{192} \mathrm{Os}\right)$. IR $\left(\mathrm{CH}_{2} \mathrm{Cl}_{2}, v(\mathrm{CO})\right)$ : $2106(\mathrm{~m}), 2054$ (vs), $2018(\mathrm{~s})$, 2000 (s), $1987(\mathrm{~m}), 1968(\mathrm{~m}), 1922(\mathrm{~m}, \mathrm{br}) \mathrm{cm}^{-1} .{ }^{1} \mathrm{H}$ NMR ( $\mathrm{C}_{6} \mathrm{D}_{6}$, $\left.23^{\circ} \mathrm{C}\right): \delta 3.60-0.90\left(\mathrm{~m}, \mathrm{CH}_{2}\right) .{ }^{13} \mathrm{C}\left\{{ }^{1} \mathrm{H}\right\} \mathrm{NMR}\left(\mathrm{C}_{6} \mathrm{D}_{6}, 23^{\circ} \mathrm{C}\right): \delta$ 177.6 (CO), 175.7, 170.4 (C $4 \mathrm{Os}), 81.9,80.0(\mathrm{C} \equiv \mathrm{C}), 45.4,33.1$, $32.5,31.2,30.2,28.1,27.3,26.4,19.2,17.5\left(\mathrm{CH}_{2}\right)$.

Reaction of $\mathbf{F e}_{3}(\mathbf{C O})_{12}$ and $\mathbf{C}_{\mathbf{1 4}} \mathbf{H}_{\mathbf{2 0}} \cdot \mathrm{C}_{14} \mathrm{H}_{20}(40 \mathrm{mg}, 0.213$ $\mathrm{mmol})$ and $\mathrm{Fe}_{3}(\mathrm{CO})_{12}(58 \mathrm{mg}, 0.115 \mathrm{mmol})$ were dissolved in $\mathrm{n}$-hexane $(10 \mathrm{~mL})$ under an atmosphere of dinitrogen. The solution was heated to reflux for $1 \mathrm{~h}$ and cooled to room temperature, and the solvent was removed on a rotary
Table 1. Crystallographic Data for $\left(\mathrm{Os}_{3}(\mathrm{CO})_{10}\right)_{2}\left(\mu_{3}, \mu_{3}-\eta^{2}, \eta^{2}-\mathrm{C}_{14} \mathrm{H}_{20}\right)$ (2), $(\mu-\mathrm{H}) \mathrm{Os}_{3}(\mathrm{CO})_{9}\left(\mu_{3}-\eta^{3}-\mathrm{C}_{14} \mathrm{H}_{19}\right)(3)$, and $\mathrm{Os}_{3}(\mathrm{CO})_{9}\left(\mu-\eta^{4}-\left(\mathrm{C}_{14} \mathrm{H}_{20}\right)_{2}\right)(4)$

\begin{tabular}{|c|c|c|c|}
\hline & 3 & 2 & 4 \\
\hline $\begin{array}{l}\text { chem formula } \\
\text { cryst solvent }\end{array}$ & $\mathrm{C}_{23} \mathrm{H}_{20} \mathrm{O}_{9} \mathrm{OS}_{3}$ & $\begin{array}{l}\mathrm{C}_{34} \mathrm{H}_{20} \mathrm{O}_{20} \mathrm{Os}_{6} \\
2 \mathrm{THF}\end{array}$ & $\mathrm{C}_{37} \mathrm{H}_{40} \mathrm{O}_{9} \mathrm{OS}_{3}$ \\
\hline crysl syst & monoclinic & monodinic & orthorhombic \\
\hline space group & $\mathrm{P} 2_{1} / \mathrm{C}$ & $\mathrm{P} 2 \mathrm{l} / \mathrm{n}$ & $\mathrm{Pmn} 2_{1}$ \\
\hline fw & 1012.00 & 2033.91 & 1199.29 \\
\hline a, $\AA$ & $17.634(5)$ & $9.3471(3)$ & 21.0938(2) \\
\hline b, $\AA$ & $9.083(3)$ & $26.7446(7)$ & $10.6494(2)$ \\
\hline$c, \AA$ & $16.756(5)$ & 10.3312(3) & $8.4656(1)$ \\
\hline$\alpha$, deg & 90 & 90 & 90 \\
\hline$\beta$, deg & 102.06(3) & 94.804(1) & 90 \\
\hline$\gamma$, deg & 90 & 90 & 90 \\
\hline$V, \AA^{3}$ & $2625(1)$ & 2573.6(1) & 1901.68(5) \\
\hline Z & 4 & 2 & 2 \\
\hline$D_{\text {calcd }}, \mathrm{g} \mathrm{cm}^{-3}$ & 2.561 & 2.625 & 2.094 \\
\hline$\mu, \mathrm{cm}^{-1}$ & 145.500 & 148.29 & 100.48 \\
\hline $\begin{array}{l}R / R_{w}{ }^{a} \\
R 1 / w R>b\end{array}$ & $0.041 / 0.036$ & 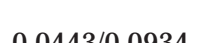 & 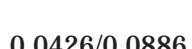 \\
\hline GOF & 1.44 & & $0.04 \angle 0 / 0.0000$ \\
\hline GOF on $F^{2}$ & & 1.076 & 1.074 \\
\hline
\end{tabular}

evaporator. The residue was subjected to TLC, with petrol eum ether as eluent. A major brown band was isolated to give $\mathrm{Fe}_{3}-$ $(\mathrm{CO})_{9}\left(\mu_{3}-\eta^{2}-\mathrm{C}_{14} \mathrm{H}_{20}\right)(5 ; 21 \mathrm{mg}, 41 \%)$. Mass spectrum (FAB): $\mathrm{m} / \mathrm{z}$ $608\left(\mathrm{M}^{+}, 56 \mathrm{Fe}\right)$. IR (n-hexane, $\left.v(\mathrm{CO})\right): 2080(\mathrm{w}), 2062(\mathrm{vw}), 2027$ (vs), 2019 (vs), 1998 (s), 1989 (m), 1970 (vw) cm ${ }^{-1}$. ${ }^{1} \mathrm{H}$ NMR $\left(\mathrm{C}_{6} \mathrm{D}_{6}, 23{ }^{\circ} \mathrm{C}\right): \delta 3.29(\mathrm{~m}, 2 \mathrm{H}), 1.97(\mathrm{~m}, 6 \mathrm{H}), 1.45-1.25(\mathrm{~m}$, $10 \mathrm{H}), 1.00(\mathrm{~m}, 2 \mathrm{H}) .{ }^{13} \mathrm{C}\left\{{ }^{1} \mathrm{H}\right\}$ NMR $\left(\mathrm{C}_{6} \mathrm{D}_{6}, 23^{\circ} \mathrm{C}\right): \delta 212.4(\mathrm{CO})$, 208.4, 105.7 ( $\equiv \mathrm{C}-\mathrm{Fe}), 81.8,79.3(\mathrm{C} \equiv \mathrm{C}), 47.8,32.5,30.8,30.5$, 29.9, 29.7, 27.0, 25.4, 18.7, $16.6\left(\mathrm{CH}_{2}\right)$.

Structure Determination for 3. A yellow crystal of ( $\mu$ $\mathrm{H}) \mathrm{Os}_{3}(\mathrm{CO})_{9}\left(\mu_{3}-\eta^{3}-\mathrm{C}_{14} \mathrm{H}_{19}\right)$ (3; ca. $\left.0.25 \times 0.30 \times 0.40 \mathrm{~mm}\right)$ was mounted in a thin-walled glass capillary and aligned on the Nonius CAD-4 diffractometer with graphite-monochromated Mo $K \alpha$ radiation $(\lambda=0.7107 \AA)$. Lattice parameters were determined from 25 randomly selected reflections with $2 \theta$ ranging from 19.5 to $24.4^{\circ}$. The data were collected at $298 \mathrm{~K}$ using the $\theta / 2 \theta$ scan technique to maximum $2 \theta$ values of $50.0^{\circ}$ at a variable speed of $3.30-8.24 \% \mathrm{~min}$. The intensities of three representative reflections, which were measured every $60 \mathrm{~min}$ of X-ray exposure time, remained constant through data collection; ther efore, no decay correction was applied. All data were corrected for Lorentz and polarization effects and for the effects of absorption. The structure was solved by the direct method and refined by least-squares cycles. The non-hydrogen atoms were refined anisotropically. Hydrogen atoms were included but not refined. All calculations were performed using the NRCSDP-VAX package. A summary of relevant crystallographic data is provided in Table 1.

Structure Determination for 2 and 4. A yellow crystal of $\left(\mathrm{Os}_{3}(\mathrm{CO})_{10}\right)_{2}\left(\mu_{3}, \mu_{3}-\eta^{2}, \eta^{2}-\mathrm{C}_{14} \mathrm{H}_{20}\right)(2 ; \mathrm{ca} .0 .20 \times 0.25 \times 0.35 \mathrm{~mm})$ and a purple crystal of $\mathrm{Os}_{3}(\mathrm{CO})_{9}\left(u-\eta^{4}-\left(\mathrm{C}_{14} \mathrm{H}_{20}\right)_{2}\right)(\mathbf{4}$; ca. $0.30 \times$ $0.08 \times 0.04 \mathrm{~mm}$ ) were each mounted in a thin-walled glass capillary and aligned on the Siemens SMART-CCD diffractometer with graphite-monochromated Mo K $\alpha$ radiation $(\lambda=$ $0.71073 \AA$ ). The $\theta$ range for data collection is $1.52-27.49^{\circ}$ for 2 and $1.91-29.92^{\circ}$ for 4 . A total of 11594 reflections were measured, and 5896 reflections $\left(R_{\text {int }}=0.0598\right)$ were unique for 2, while 14882 reflections were measured and 4313 reflections $\left(R_{\text {int }}=0.0685\right)$ were unique for $\mathbf{4}$. Sadabs absorption corrections were made for $\mathbf{2}\left(T_{\min }=0.0869, T_{\max }=0.2649\right)$ and $4\left(\mathrm{~T}_{\min }=0.1459, \mathrm{~T}_{\max }=0.3576\right)$. The structures were solved by the direct method and refined by full-matrix least squares on $\mathrm{F}^{2}$. The program used was the SHELXTLE package. The data collection and refinement parameters are collected in Table 1 . The space group $\mathrm{Pmn}_{1}$ for $\mathbf{4}$ is acentric; 


\section{Scheme 1}

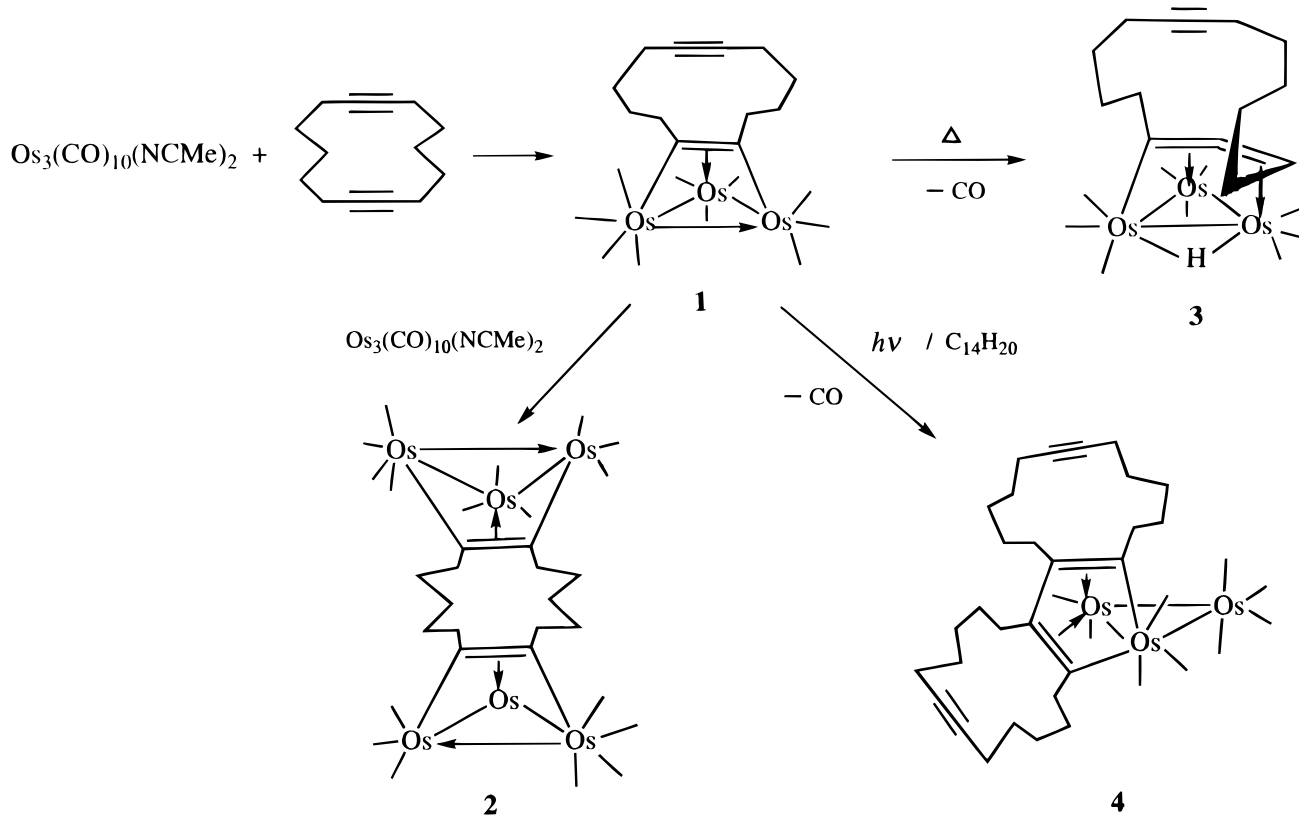

thus, in the course of the final structure factor calculation the program calculates the Flack ${ }^{9}$ absolute structure factor $x$ and its esd. A comparison of $x$ with its esd provides an indication as to whether the refined absolute structure is correct or whether it has to be "inverted". The true value of $\mathrm{x}$ is close to zero.

\section{Results and Discussion}

Synthesis. The reactions of cyclotetradeca-1,8-diyne $\left(\mathrm{C}_{14} \mathrm{H}_{20}\right)$ and triosmium clusters are summarized in Scheme 1. $\mathrm{Os}_{3}(\mathrm{CO})_{10}(\mathrm{NCMe})_{2}$ reacts with $\mathrm{C}_{14} \mathrm{H}_{20}$ in hot benzene to produce $\mathrm{Os}_{3}(\mathrm{CO})_{10}\left(\mu_{3}-\eta^{2}-\mathrm{C}_{14} \mathrm{H}_{20}\right)(\mathbf{1} ; 86 \%)$ and the $\mathrm{Os}_{6}-$ diyne cluster $\left(\mathrm{Os}_{3}(\mathrm{CO})_{10}\right)_{2}\left(\mu_{3}, \mu_{3}-\eta^{2}, \eta^{2}-\mathrm{C}_{14} \mathrm{H}_{20}\right)(2$; $11 \%)$ after purification by TLC and recrystallization. Further treatment of $\mathbf{1}$ with $\mathrm{Os}_{3}(\mathrm{CO})_{10}(\mathrm{NCMe})_{2}$ affords 2 in 53\% yield, suggesting a stepwise formation of the compounds 1 and 2 . Preparation of $\mathrm{Os}_{3}(\mathrm{CO})_{10}($ alkyne) complexes from $\mathrm{Os}_{3}(\mathrm{CO})_{10}(\mathrm{NCMe})_{2}$ and the corresponding al kyne ligands is well-established, ${ }^{10-15}$ whereas the cyclodiyne-bridged double cluster $\mathbf{2}$ is unprecedented.

Thermolysis of $\mathbf{1}$ in refluxing n-heptane $\left(98^{\circ} \mathrm{C}\right)$ leads to a CO loss together with an $\alpha-\mathrm{C}-\mathrm{H}$ bond activation of the alkyne ligand to form the hydrido allene complex $(\mu-\mathrm{H}) \mathrm{Os}_{3}(\mathrm{CO})_{9}\left(\mu_{3}-\eta^{3}-\mathrm{C}_{14} \mathrm{H}_{19}\right)(3)$ in $90 \%$ yield. Analogous transformations were previously observed for thermal reaction of $\mathrm{Os}_{3}(\mathrm{CO})_{10}\left(\mu_{3}-\eta^{2}-\mathrm{C}_{2} \mathrm{Me} e_{2}\right)$ to give $(\mu-\mathrm{H}) \mathrm{Os}_{3}(\mathrm{CO})_{9}$ -

(9) Flack, H. D. Acta Crystallogr. 1983, A39, 876

(10) (a) Tachikawa, M.; Shapley, J . R.; Pierpont, C. G. J . Am. Chem. Soc. 1975, 97, 7172. (b) Tachikawa, M.; Shapley, J . R. J . Organomet. Chem. 1977, 124, C19.

(11) Pierpont, C. G. Inorg. Chem. 1977, 16, 636.

(12) Rosenberg, E.; Bracker-Novak, J .; Gellert, R. W.; Aime, S.; Gobetto, R.; Osella, D. J . Organomet. Chem. 1989, 365, 163.

(13) (a) Hardcastle, K. I.; McPhillips, T.; Arce, A. J .; De Sanctis, Y.; Deeming, A. J .; Powell, N. I. J . Organomet. Chem. 1990, 389, 361. (b) Deeming, A. J .; Senior, A. M. J . Organomet. Chem. 1992, 439, 177. (c) Deeming, A. J .; Felix, M. S. B.; Nuel, D. Inorg. Chim. Acta 1993, 213, 3. (d) Hardcastle, K. I.; Deeming, A. J .; Nuel, D.; Powell, N. I. J Organomet. Chem. 1989, 375, 217.

(14) (a) J ackson, W. G.; J ohnson, B. F. G.; Kelland, J . W.; Lewis, J .; Schorpp, K. T. J . Organomet. Chem. 1975, 87, C27. (b) Lewis, J Massey, A. D.; Monari, M.; J ohnson, B. F. G.; Braga, D.; Grepioni, F. J. Chem. Soc., Dalton Trans. 1992, 249.

(15) Bruce, M. I.; Skelton, B. W.; White, A. H.; Zaitseva, N. N. Aust. J. Chem. 1996, 49, 155.

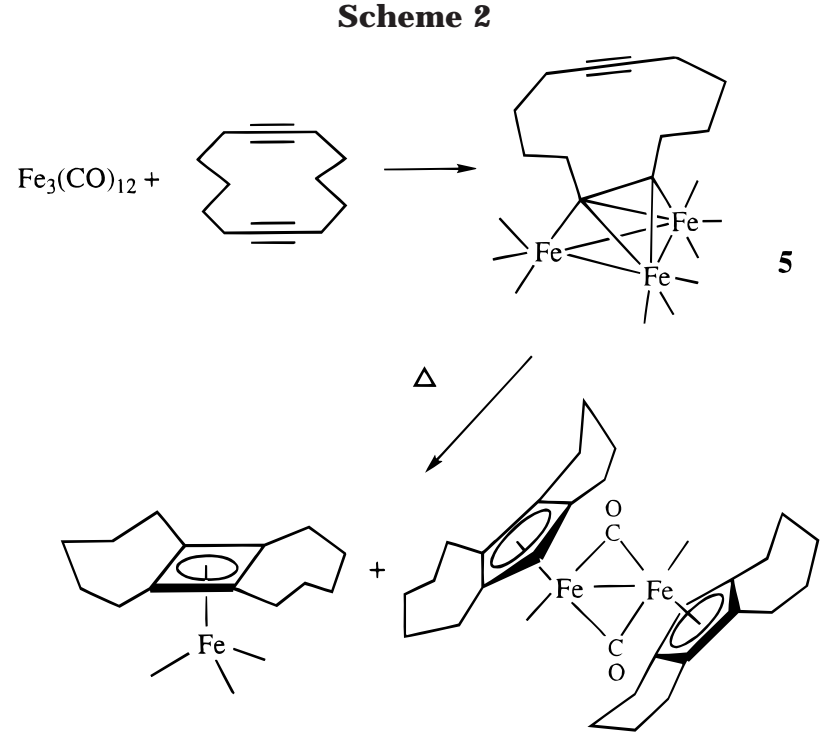

$\left(\mu_{3}-\eta^{3}-\mathrm{MeC}=\mathrm{C}=\mathrm{CH}_{2}\right),{ }^{16}$ of $\mathrm{Os}_{3}(\mathrm{CO})_{10}\left(\mu_{3}-\eta^{2}-\mathrm{C}_{2}\left(\mathrm{C}_{2} \mathrm{Et}\right) \mathrm{Et}\right)$ to give $(\mu-\mathrm{H}) \mathrm{Os}_{3}(\mathrm{CO})_{9}\left(u_{3}-\eta^{3}-\left(\mathrm{C}_{2} \mathrm{Et}\right) \mathrm{C}=\mathrm{C}=\mathrm{C}(\mathrm{Me}) \mathrm{H}\right),{ }^{13,17}$ and of $\mathrm{Os}_{3}(\mathrm{CO})_{10}\left(\mu_{3}-\eta^{2}-\mathrm{C}_{2} \mathrm{Et}_{2}\right)$ to give $(\mu-\mathrm{H}) \mathrm{Os}_{3}(\mathrm{CO})_{9}\left(\mu_{3}-\eta^{3}-\right.$ $\mathrm{EtC}=\mathrm{C}=\mathrm{C}(\mathrm{Me}) \mathrm{H}),{ }^{18}$ while thermolysis of the di phenylacetylene complex $\mathrm{Os}_{3}(\mathrm{CO})_{10}\left(\mu_{3}-\eta^{2}-\mathrm{C}_{2} \mathrm{Ph}_{2}\right)$ led only to decarbonylation to afford the highly reactive species $\mathrm{Os}_{3}(\mathrm{CO})_{9}\left(\mathrm{C}_{2} \mathrm{Ph}_{2}\right) \cdot{ }^{19}$ On the other hand, $\mathrm{Fe}_{3}(\mathrm{CO})_{12}$ reacts with $\mathrm{C}_{14} \mathrm{H}_{20}$ to generate $\mathrm{Fe}_{3}(\mathrm{CO})_{9}\left(\mu_{3}-\eta^{2}-\mathrm{C}_{14} \mathrm{H}_{20}\right)$ (5), which undergoes cluster fragmentation to produce $\left(\eta^{4}-\right.$ $\left.\mathrm{C}_{4}\left(\mathrm{C}_{10} \mathrm{H}_{20}\right)\right) \mathrm{Fe}(\mathrm{CO})_{3}$ and $\left[\left(\eta^{5}-\mathrm{C}_{5}\left(\mathrm{C}_{9} \mathrm{H}_{18}\right)\right) \mathrm{Fe}(\mathrm{CO})_{2}\right]_{2}$ in refluxing heptane (Scheme 2). The last two compounds were previously reported by $\mathrm{King}^{20}$ from the thermal

(16) Deeming, A. J .; Hasso, S.; Underhill, M. J . Chem. Soc., Dalton Trans. 1975, 1614

(17) Deeming, A. J .; Felix, M. S. B.; Bates, P. A.; Hursthouse, M. B. J. Chem. Soc., Chem. Commun. 1987, 461.

(18) Bracker-Novak, J .; Hajela, S.; Lord, M.; Zhang, M.; Rosenberg, E.; Gobetto, R.; Milone, L.; Osella, D. Organometallics 1990, 9, 1379.

(19) Clauss, A. D.; Shapley, J . R.; Wilson, S. R. J . Am. Chem. Soc. 1981, 103, 7387

(20) (a) King, R. B.; Haiduc, I. J . Am. Chem. Soc. 1972, 94, 4044. (b) King, R. B.; Haiduc, I.; Eavenson, C. W. J . Am. Chem. Soc. 1973 95,2508 . 
reaction of $\mathrm{Fe}_{3}(\mathrm{CO})_{12}$ and cyclotetradeca-1,8-diyne, but the intermediate $\mathbf{5}$ was not observed in that study.

Photoi rradiation of $\mathbf{1}$ in the presence of $\mathrm{C}_{14} \mathrm{H}_{20}$ ligand affords the osmacyclopentadienyl complex $\mathrm{Os}_{3}(\mathrm{CO})_{9}(\mu$ $\left.\eta^{4}-\mathrm{C}_{4}\left(\mathrm{C}_{12} \mathrm{H}_{20}\right)_{2}\right)(\mathbf{4})$ in $48 \%$ yield, whereas co-thermolysis of $\mathbf{1}$ and $\mathrm{C}_{14} \mathrm{H}_{20}$ produces mainly $\mathbf{2}$. Similar metallacyclopentadienyl complexes were obtained from thermal reactions of $\mathrm{Os}_{3}(\mathrm{CO})_{10}\left(\mu_{3}-\eta^{2}-\mathrm{C}_{2} \mathrm{R}_{2}\right)$ with $\mathrm{C}_{2} \mathrm{R}_{2}(\mathrm{R}=\mathrm{Ph}$, $\mathrm{Me})^{21-23}$ and of $\mathrm{Ru}_{3}(\mathrm{CO})_{8}(\mu-\mathrm{dppm})\left(\mu_{3}-\eta^{2}-\mathrm{C}_{2}\left(\mathrm{CO}_{2} \mathrm{Me}\right)_{2}\right)$ with $\mathrm{C}_{2} \mathrm{Ph}_{2} \cdot{ }^{24}$

Recently, the bis(alkyne) complexes $\mathrm{Os}_{3}(\mathrm{CO})_{8}\left(\mathrm{C}_{2} \mathrm{R}_{2}\right)$ $\left(C_{2} R_{2}^{\prime}\right)\left(R, R^{\prime}=M e, P h\right)$ were prepared by treating a solution of $\mathrm{Os}_{3}(\mathrm{CO})_{10}\left(\mathrm{C}_{2} \mathrm{R}_{2}\right)$ in $\mathrm{CH}_{2} \mathrm{Cl}_{2}$ with $\mathrm{Me}_{3} \mathrm{NO} /$ $\mathrm{MeCN}$ in the presence of $\mathrm{C}_{2} \mathrm{R}_{2}{ }_{2}{ }^{25}$ The molecular structure of $\mathrm{Os}_{3}(\mathrm{CO})_{8}\left(\mathrm{C}_{2} \mathrm{Ph}_{2}\right)_{2}^{25 a}$ shows the two alkyne ligands capping the opposite triosmi um faces in a $\mu_{3}-\eta^{2}-||$-mode. Our preliminary investigation on the reaction of $\mathbf{1}$ with $\mathrm{Me}_{3} \mathrm{NO}$ indicates the formation of $\left[\mathrm{Os}_{3}(\mathrm{CO})_{8}\right]_{\times}$oligomers linked by the cycl odiyne ligands. Further characterization of the products is under way.

Spectroscopic Characterization of New Compounds. Compounds $\mathbf{1 - 5}$ form air-stable crystalline solids and have been characterized by mass, IR, and NMR spectroscopy.

The FAB mass spectrum of $\mathbf{1}$ presents the molecular ion peak at $\mathrm{m} / \mathrm{z} 1044$ for ${ }^{192} \mathrm{Os}$. The solution IR spectrum in the carbonyl region of $\mathbf{1}$ (Figure $1 \mathrm{la}$ ) is in close agreement with those of mono(alkyne) complexes of the type $\mathrm{Os}_{3}(\mathrm{CO})_{9}(\mu-\mathrm{CO})\left(\mu_{3}-\eta^{2}-\mathrm{C}_{2} \mathrm{R}_{2}\right)\left(\mathrm{R}=\mathrm{Et},{ }^{12} \mathrm{CO}_{2} \mathrm{Me}^{13 \mathrm{~b}}\right)$, each of which contains a bridging $\mathrm{CO}$ ligand $(\nu(\mathrm{CO}) \mathrm{ca}$. $1850 \mathrm{~cm}^{-1}$ ) and has the coordinated alkyne $\mathrm{C}-\mathrm{C}$ bond approximately parallel to an Os-Os edge. The ${ }^{1} \mathrm{H}$ and ${ }^{13} \mathrm{C}$ NMR data of $\mathbf{1}$ are consistent with a molecule of idealized $C_{s}$ symmetry in solution. The ${ }^{13} \mathrm{C}$ resonances for the coordinated and free alkyne carbons are at $\delta$ 148.4 and 80.7, respectively, while the carbonyl ligands are fluxional at $23^{\circ} \mathrm{C}$ to give one broad resonance at $\delta$ 178.

While 1 has a good solubility in common organic solvents, $\left(\mathrm{Os}_{3}(\mathrm{CO})_{10}\right)_{2}\left(\mu_{3}, \mu_{3}-\eta^{2}, \eta^{2}-\mathrm{C}_{14} \mathrm{H}_{20}\right)(2)$ is sparingly soluble in THF and dichloromethane. The FAB mass spectrum of $\mathbf{2}$ gives the molecular ion peak at m/z 1900 for ${ }^{192} \mathrm{Os}$. I ts NMR spectra displays only three sets of ${ }^{1} \mathrm{H}$ resonances at $\delta 2.14,2.02$, and 1.45 in a 2:2:1 ratio and four ${ }^{13} \mathrm{C}$ resonance signals at $\delta 150(\mathrm{C} \equiv \mathrm{C}), 50.6$, 42.2 , and 34.0 for the $\mathrm{C}_{14} \mathrm{H}_{20}$ ligand, suggesting a symmetric structure for $\mathbf{2}$. Since the solution IR spectrum does not present a clear absorption for bridging carbonyl, a single-crystal X-ray diffraction study of $\mathbf{2}$ was conducted.

$(u-\mathrm{H}) \mathrm{Os}_{3}(\mathrm{CO})_{9}\left(\mu_{3}-\eta^{3}-\mathrm{C}_{14} \mathrm{H}_{19}\right)(3)$ forms yell ow crystals. Its $F A B$ mass spectrum displays the molecular ion peak at $\mathrm{m} / \mathrm{z}=1016$, which is 28 less than that of $\mathbf{1}$ to indicate a CO loss during the thermolysis process. The ${ }^{1} \mathrm{H} N M R$ spectrum of 3 shows a hydride resonance at $\delta-22.03$

(21) Gambino, O.; Ferrari, R. P.; Chinone, M.; Vaglio, G. A. Inorg. Chim. Acta 1975, 12, 155.

(22) Gallop, M. A.; J ohnson, B. F. G.; Khattar, R.; Lewis, J .; Raithby, P. R. J . Organomet. Chem. 1990, 386, 121.

(23) Poë, A.J .; Farrar, D. H.; Ramachandran, R.; Moreno, C. Inorg. Chim. Acta 1998, 274, 82.

(24) Bruce, M. I.; Hinchliffe, J . R.; Humphrey, P. A.; Surynt, R. J .; Skelton, B. W.; White, A. H. J . Organomet. Chem. 1998, 552, 109.

(25) (a) J ohnson, B. F. G.; Khattar, R.; Lahoz, F. J .; Lewis, J .; Raithby, P. R. J. Organomet. Chem. 1987, 319, C51. (b) J ohnson, B. F. G.; K hattar, R.; Lewis, J .; Raithby, P. R. J . Organomt. Chem. 1987 335, C17. (c) Housecroft, C. E.; Owen, S. M. J . Organomet. Chem. 1988, 339, 139.

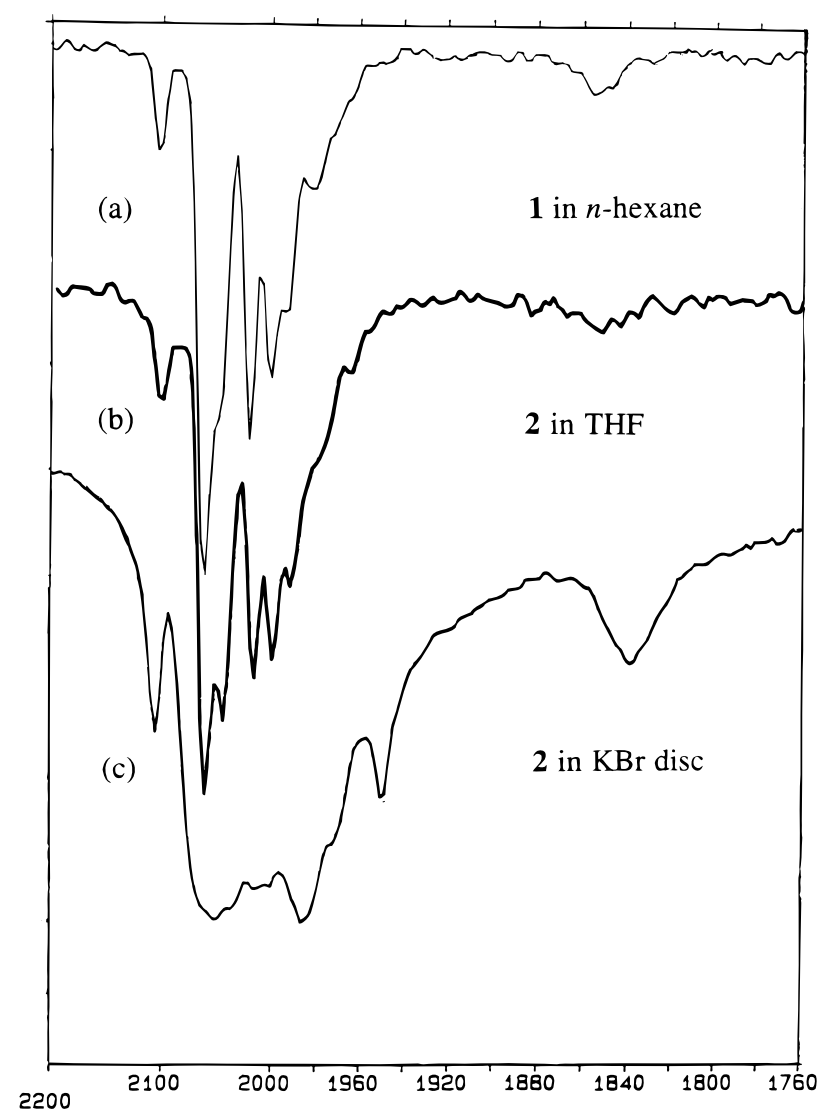

Figure 1. I R spectra in the carbonyl region: (a) $\mathrm{Os}_{3}(\mathrm{CO})_{10^{-}}$ $\left(\mu_{3}-\eta^{2}-\mathrm{C}_{14} \mathrm{H}_{20}\right)(\mathbf{1})$ in $\mathrm{n}$-hexane solvent; (b) $\left(\mathrm{Os}_{3}(\mathrm{CO})_{10}\right)_{2}\left(\mu_{3}, \mu_{3}\right.$ $\left.\eta^{2}, \eta^{2}-\mathrm{C}_{14} \mathrm{H}_{20}\right)$ (2) in THF solvent; (c) $\left(\mathrm{Os}_{3}(\mathrm{CO})_{10}\right)_{2}\left(\mu_{3}, \mu_{3}-\eta^{2}, \eta^{2}-\right.$ $\left.\mathrm{C}_{14} \mathrm{H}_{20}\right)(2)$ in a $\mathrm{KBr}$ disk.

and a complex multiplet in the region $\delta$ 2.86-0.86 $(19 \mathrm{H})$, indicating a $\mathrm{C}-\mathrm{H}$ activation of the diyne ligand on the cluster. A single-crystal X-ray diffraction study was performed for $\mathbf{3}$ to establish its structure.

$\mathrm{Os}_{3}(\mathrm{CO})_{9}\left(u-\eta^{4}-\mathrm{C}_{4}\left(\mathrm{C}_{12} \mathrm{H}_{20}\right)_{2}\right)$ (4) forms purple crystals. Its intense color indicates the presence of a metallacycle. ${ }^{26}$ The $F A B$ mass spectrum of $\mathbf{4}$ displays the molecular ion peak at $\mathrm{m} / \mathrm{z} 1204$ corresponding to a CO loss $(-28)$ plus a diyne ligand addition $(+188)$ from 1. The ${ }^{13} \mathrm{C}$ NMR spectrum shows resonances for free alkyne carbons at $\delta 81.9$ and 80.0, while no resonances around $\delta 150$ for coordinated alkyne carbons are observed. A single crystal of $\mathbf{4}$ was thus subjected to an X-ray diffraction analysis.

Compound 5 forms brown crystalline solids. The FAB spectrum shows the molecular ion peak at $\mathrm{m} / \mathrm{z} 608$ for ${ }^{56} \mathrm{Fe}$. The IR absorptions in the carbonyl region shows a pattern similar to that recorded for $\mathrm{Fe}_{3}(\mathrm{CO})_{9}\left(\mu_{3}-\eta^{2}-\right.$ $\left.\mathrm{C}_{2} \mathrm{R}_{2}\right)\left(\mathrm{R}=\mathrm{Et},{ }^{27} \mathrm{Ph}^{28}\right)$, in which the alkyne triple bond is disposed above the $\mathrm{Fe}_{3}$ plane and perpendicular to one of the $\mathrm{Fe}-\mathrm{Fe}$ edges, with one acetylenic carbon in a $\mu_{3}$ mode and the other in a $\mu_{2}$ mode. The ${ }^{13} \mathrm{C}$ NMR spectrum of $\mathbf{5}$ includes two coordinated al kyne carbon resonances at $\delta 208.4$ and 105.7 and two free alkyne carbon resonances at $\delta 81.8$ and 79.3, consistent with the proposed structure.

(26) Sappa, E.; Tiripicchio, A.; Braunstein, P. Chem. Rev. 1983, 83 , 203.

(27) Carty, A. J .; Taylor, N.; Sappa, E. Organometallics 1988, 7, 405. (28) Blount, J . F.; Dahl, L. F .; H oogzand, C.; Hübel, W. J . Am. Chem. Soc. 1966, 88, 292. 


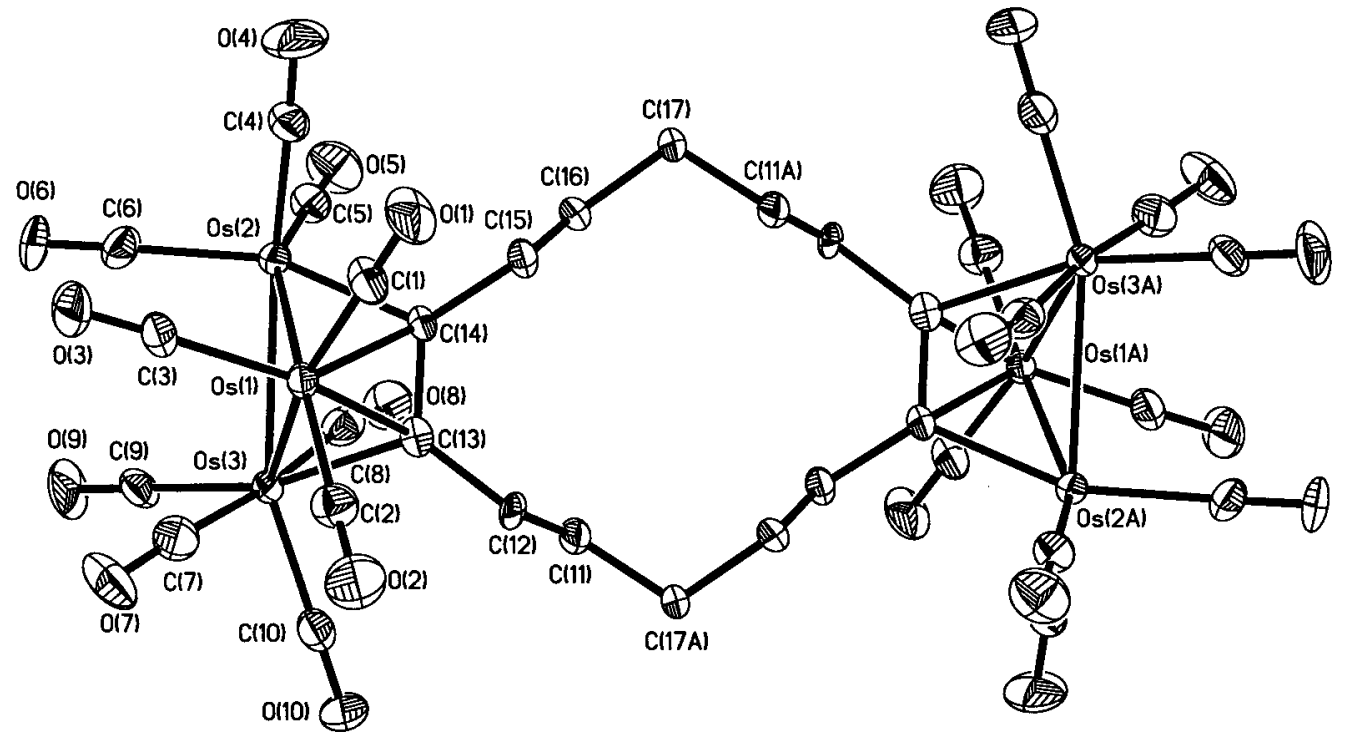

Figure 2. Molecular structure of $\left(\mathrm{Os}_{3}(\mathrm{CO})_{10}\right)_{2}\left(\mu_{3}, \mu_{3}-\eta^{2}, \eta^{2}-\mathrm{C}_{14} \mathrm{H}_{20}\right)$ (2). The hydrogen atoms have been artificially omitted for clarity.

Crystal Structure of 2. Crystals of $\left(\mathrm{Os}_{3}(\mathrm{CO})_{10}\right)_{2-}$ $\left(\mu_{3}, \mu_{3}-\eta^{2}, \eta^{2}-\mathrm{C}_{14} \mathrm{H}_{20}\right)$ (2) contain an ordered array of discrete monomeric molecular units which are mutually separated by normal van der Waals distances. The ORTEP diagram (Figure 2 ) shows that the two alkyne triple bonds of the $\mathrm{C}_{14} \mathrm{H}_{20}$ ligand are each bonded to an $\mathrm{Os}_{3}(\mathrm{CO})_{10}$ cluster in a $\mu_{3}-\eta^{2}$ mode. There is a crystallographic center of symmetry imposed on the molecule. Important interatomic distances and intramolecular angles are collected in Table 2.

The metal parts are based upon a triangular array of osmium atoms in which the Os(3)-Os(2) interaction is properly described as a dative bond by donating two nonbonding el ectrons from Os(3) to Os(2) to satisfy the 18-electron rule for each osmium atom. The distances of the electron-rich $\mathrm{Os}(3)$ atom to Os(2) and Os(1) atoms at 2.8776(5) and 2.8570(5) $\AA$, respectively, are significantly longer than the Os(1)-Os(2) distance of 2.7087(6) $\AA$. The alkyne $C(13)-C(14)$ unit is asymmetrically bonded to three osmium atoms, formally forming a $\pi$ bond to Os(1) and $\sigma$ bonds to Os(2) and Os(3). The donor ability of the alkyne ligand is weaker to the electronrich metal Os(3), with a length of 2.21(1) $\AA$ to $C(13)$, than to electron-deficient Os(2), with an Os(2)-C(14) length of $2.11(1) \AA$. In return, the $\mathrm{Os}(1)-\mathrm{C}(13)$ distance $(2.153(9) \AA)$ is significantly shorter than the Os(1)$C(14)$ distance $(2.29(1) \AA)$. The $C(13)-C(14)$ vector is slightly tilted $\left(4.2^{\circ}\right)$ with respect to the Os(3)-Os(2) edge. The $\mathrm{C}(13), \mathrm{C}(14), \mathrm{Os}(2)$, and $\mathrm{Os}(3)$ atoms are coplanar to within $0.08 \AA$, and the dihedral angle between this plane and the triosmium plane is $56.6^{\circ}$.

The Os(1) and Os(2) atoms are each linked to three terminal carbonyl ligands, with the Os-CO lengths in the range 1.87(1)-1.97(1) $\AA$ and the Os- $\mathrm{C}-\mathrm{O}$ angles in the range $178(1)-179(1)^{\circ}$. Four carbonyl ligands are bonded to the Os(3) atom with slightly longer Os-C lengths, ranging from $1.94(1)$ to $1.98(1) \AA$. The Os(3)$C(9)-C(9)$ and Os(3)-C(10)-C(10) angles are 179(1) ${ }^{\circ}$, while the $\mathrm{Os}(3)-\mathrm{C}(7)-\mathrm{O}(7)$ and $\mathrm{Os}(3)-\mathrm{C}(8)-\mathrm{O}(8)$ angles are $166(1)$ and $171(1)^{\circ}$, respectively. The last two Os$\mathrm{C}-\mathrm{O}$ angles deviate slightly but significantly from linearity and show weak bonding with the adjacent Os
Table 2. Selected Bond Distances $(\AA \AA)$ and Bond Angles (deg) for $\left(\mathrm{OS}_{3}(\mathrm{CO})_{10}\right)_{2}\left(\mu_{3}, \mu_{3}-\eta^{2}, \eta^{2}-\mathrm{C}_{14} \mathrm{H}_{20}\right)(2)$

\begin{tabular}{llll} 
& \multicolumn{3}{c}{ Distances } \\
Os(1)-Os(2) & $2.7087(6)$ & Os(1)-Os(3) & $2.8570(5)$ \\
Os(2)-Os(3) & $2.8776(5)$ & Os(1)-C(1) & $1.88(1)$ \\
Os(1)-C(2) & $1.94(1)$ & Os(1)-C(3) & $1.91(1)$ \\
Os(2)-C(4) & $1.90(1)$ & Os(2)-C(5) & $1.87(1)$ \\
Os(2)-C(6) & $1.97(1)$ & Os(3)-C(7) & $1.95(2)$ \\
Os(3)-C(8) & $1.98(1)$ & Os(3)-C(9) & $1.97(1)$ \\
Os(3)-C(10) & $1.94(1)$ & $\mathrm{C}(1)-O(1)$ & $1.14(1)$ \\
C(2)-O(2) & $1.13(1)$ & $\mathrm{C}(3)-O(3)$ & $1.13(1)$ \\
C(4)-O(4) & $1.13(1)$ & $\mathrm{C}(5)-\mathrm{O}(5)$ & $1.18(2)$ \\
C(6)-O(6) & $1.10(1)$ & $\mathrm{C}(7)-\mathrm{O}(7)$ & $1.15(2)$ \\
$\mathrm{C}(8)-\mathrm{O}(8)$ & $1.12(1)$ & $\mathrm{C}(9)-\mathrm{O}(9)$ & $1.12(1)$ \\
$\mathrm{C}(10)-\mathrm{O}(10)$ & $1.13(1)$ & $\mathrm{Os}(1)-\mathrm{C}(13)$ & $2.153(9)$ \\
Os(1)-C(14) & $2.29(1)$ & $\mathrm{Os}(2)-\mathrm{C}(14)$ & $2.11(1)$ \\
Os(3)-C(13) & $2.21(1)$ & $\mathrm{C}(11)-\mathrm{C}(12)$ & $1.52(1)$ \\
$\mathrm{C}(11)-\mathrm{C}(17 \mathrm{~A})$ & $1.53(1)$ & $\mathrm{C}(12)-\mathrm{C}(13)$ & $1.52(1)$ \\
$\mathrm{C}(13)-\mathrm{C}(14)$ & $1.41(1)$ & $\mathrm{C}(14)-\mathrm{C}(15)$ & $1.53(1)$ \\
$\mathrm{C}(15)-\mathrm{C}(16)$ & $1.54(1)$ & $\mathrm{C}(16)-\mathrm{C}(17)$ & $1.53(1)$
\end{tabular}

\begin{tabular}{|c|c|c|c|}
\hline \multicolumn{4}{|c|}{ Angles } \\
\hline 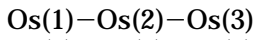 & $61.43(1)$ & $\mathrm{Os}(1)-\mathrm{Os}(3)-\mathrm{Os}(2)$ & $6.37(1)$ \\
\hline$s(2)-O s(1)-O s(3)$ & $62.20(1)$ & $\mathrm{Os}(1)-\mathrm{C}(1)-\mathrm{O}(1)$ & $178(1)$ \\
\hline$s(1)-C(2)-O(2)$ & 178(1) & $\mathrm{Os}(1)-\mathrm{C}(3)-\mathrm{O}(3)$ & 178(1) \\
\hline $5(2)-C(4)-O(4)$ & 178(1) & $\mathrm{Os}(2)-\mathrm{C}(5)-\mathrm{O}(5)$ & 17 \\
\hline $5(2)-C(6)-O(6)$ & 179(1) & $\mathrm{Os}(3)-\mathrm{c}(7)-\mathrm{O}(7)$ & 166(1) \\
\hline$s(3)-C(8)-O(8)$ & $171(1)$ & $\mathrm{Os}(3)-\mathrm{C}(9)-\mathrm{O}(9)$ & 179.8(9) \\
\hline 3) $-\mathrm{C}(10)-\mathrm{O}(10)$ & 179(1) & $\mathrm{C}(1)-\mathrm{Os}(1)-\mathrm{C}(3)$ & $90.6(5)$ \\
\hline י & $90.4(5)$ & $C(3)-$ & 103. \\
\hline & $158.0(3)$ & $C(2)$ & \\
\hline 3) - Os (1)-C(13) & $152.6(5)$ & $C(3)-O s(1)-C(14)$ & \\
\hline (4) $-\mathrm{Os}(2)-\mathrm{C}(5)$ & $93.0(5)$ & $C(4)-O s(2)-C(6)$ & $94.4(5)$ \\
\hline (5) $-O s(2)-C(6)$ & $97.6(5)$ & $C(4)-$ & \\
\hline$-O s(1)$ & $156.2(4)$ & $-C(14)$ & 157 \\
\hline (7) $-\mathrm{Os}(3)-\mathrm{C}(8)$ & $172.8(5)$ & $-C(9)$ & $84.1(5)$ \\
\hline (7)-Os(3)-C(10) & 91.5(5) & $C(8)-O s(3)-C(9)$ & $90.0(5)$ \\
\hline (8) $-\mathrm{Os}(3)-\mathrm{C}(10)$ & $93.6(5)$ & $-C(10)$ & \\
\hline$-C(13)$ & $103.3(5)$ & - Os(1) & $65.1(4)$ \\
\hline Os(3)-Os(2) & $71.7(3)$ & $-C(13)$ & $81.3(4)$ \\
\hline$C(9)-O s(3)-C(13)$ & $164.0(4)$ & $\mathrm{C}(9)-\mathrm{Os}(3)-\mathrm{Os}(2)$ & $95.5(3)$ \\
\hline & $69.0(3)$ & $\mathrm{Os}(2)-\mathrm{C}(14)-\mathrm{C}(13)$ & $111.5(7)$ \\
\hline (14) $-C(15)$ & $125.2(7)$ & $\mathrm{Os}(3)-\mathrm{Os}(2)-\mathrm{C}(14)$ & $70.7(3)$ \\
\hline $5(3)-C(13)-C(14)$ & $106.9(7)$ & $\mathrm{Os}(3)-\mathrm{C}(13)-\mathrm{C}(12)$ & $124.0(6)$ \\
\hline (13) $-\mathrm{C}(14)-\mathrm{Os}(2)$ & $111.5(7)$ & $C(13)-C(14)-C(15)$ & $123.2(9)$ \\
\hline$(13)-O s(1)-C(14)$ & $36.9(4)$ & $C(14)-C(13)-O s(3)$ & $106.9(7)$ \\
\hline
\end{tabular}

$\mathrm{C}(14)-\mathrm{C}(13)-\mathrm{C}(12) \quad 124.7(9)$

atoms, such as Os(1) $\cdots \mathrm{C}(7)=2.65(1) \AA$ and Os(2) $\cdots C(8)$ $=2.95(1) \AA$, clearly indicating a semibridging interaction. ${ }^{29}$ The crystal structure of the diphenylacetylene 


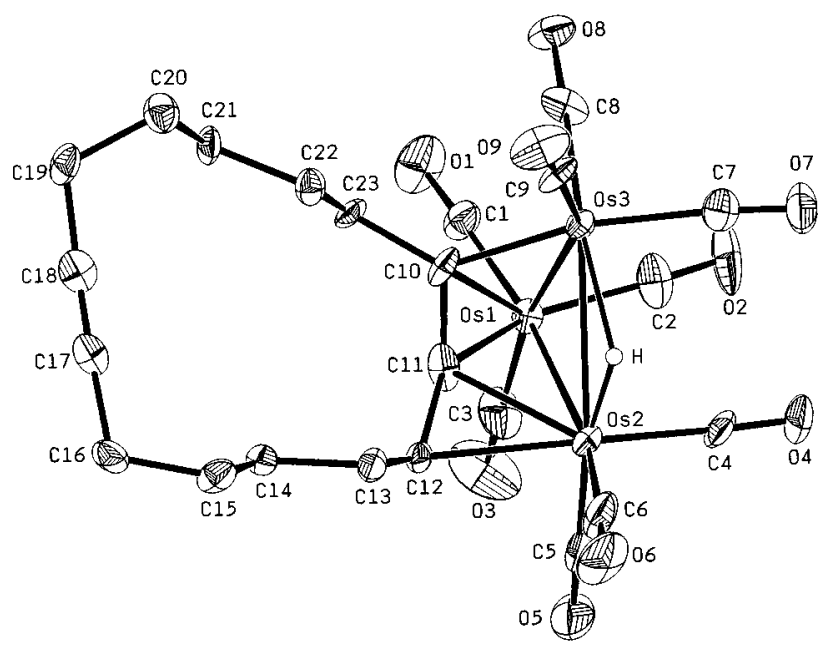

Figure 3. Molecular structure of $(\mu-\mathrm{H}) \mathrm{Os}_{3}(\mathrm{CO})_{9}\left(\mu_{3}-\eta^{3}-\right.$ $\mathrm{C}_{14} \mathrm{H}_{19}$ ) (3). The hydrogen atoms, except the bridging hydride, have been artificially omitted for clarity.

Table 3. Selected Bond Distances $(\AA)$ and Bond Angles (deg) for $(\mu-\mathrm{H}) \mathrm{Os}_{3}(\mathrm{CO})_{9}\left(\mu_{3}-\eta^{3}-\mathrm{C}_{14} \mathrm{H}_{19}\right)$ (3)

\begin{tabular}{|c|c|c|c|}
\hline \multicolumn{4}{|c|}{ Distances } \\
\hline $\mathrm{Os}(1)-\mathrm{Os}(2)$ & $2.807(1)$ & Os(1)-Os(3) & $2.793(3)$ \\
\hline $\mathrm{Os}(2)-\mathrm{Os}(3)$ & 2.992(1) & Os(1)-C(1) & $1.89(2)$ \\
\hline Os(1)-C(2) & $1.95(2)$ & $\mathrm{Os}(1)-\mathrm{C}(3)$ & $1.91(2)$ \\
\hline $\mathrm{Os}(2)-\mathrm{C}(4)$ & $1.89(1)$ & $\mathrm{Os}(2)-\mathrm{C}(5)$ & $1.89(2)$ \\
\hline $\mathrm{Os}(2)-\mathrm{C}(6)$ & $1.92(2)$ & $\mathrm{Os}(3)-\mathrm{c}(7)$ & $1.96(2)$ \\
\hline $\mathrm{Os}(3)-\mathrm{C}(8)$ & $1.85(2)$ & $\mathrm{Os}(3)-\mathrm{c}(9)$ & $1.91(2)$ \\
\hline $\mathrm{Os}(2)-\mathrm{H}$ & $1.4(1)$ & $\mathrm{Os}(3)-\mathrm{H}$ & $1.9(1)$ \\
\hline $\mathrm{C}(1)-\mathrm{O}(1)$ & $1.14(2)$ & $\mathrm{C}(2)-\mathrm{O}(2)$ & $1.11(2)$ \\
\hline$C(3)-O(3)$ & $1.12(2)$ & $C(4)-O(4)$ & $1.13(2)$ \\
\hline$C(5)-O(5)$ & $1.18(2)$ & $C(6)-O(6)$ & $1.11(2)$ \\
\hline $\mathrm{C}(7)-\mathrm{O}(7)$ & $1.13(2)$ & $\mathrm{C}(8)-\mathrm{O}(8)$ & $1.15(2)$ \\
\hline $\mathrm{C}(9)-\mathrm{O}(9)$ & $1.12(2)$ & $\mathrm{Os}(1)-\mathrm{C}(10)$ & $2.30(1)$ \\
\hline $\mathrm{Os}(1)-\mathrm{C}(11)$ & $2.10(1)$ & $\mathrm{Os}(2)-\mathrm{C}(11)$ & $2.27(2)$ \\
\hline $\mathrm{Os}(2)-\mathrm{C}(12)$ & $2.34(1)$ & $\mathrm{Os}(3)-\mathrm{C}(10)$ & $2.05(1)$ \\
\hline$C(10)-C(11)$ & $1.41(2)$ & $C(10)-C(23)$ & $1.49(2)$ \\
\hline$C(11)-C(12)$ & $1.40(2)$ & $C(12)-C(13)$ & $1.45(2)$ \\
\hline$C(17)-C(18)$ & $1.17(2)$ & & \\
\hline \multicolumn{4}{|c|}{ Angles } \\
\hline Os(2)-Os(1)-Os(3) & $64.61(3)$ & $\mathrm{Os}(1)-\mathrm{Os}(2)-\mathrm{Os}(3)$ & $57.47(3)$ \\
\hline Os(1)-Os(3)-Os(2) & $57.92(2)$ & Os(2)-Os(1)-C(1) & $163.8(5)$ \\
\hline Os(3)-Os(1)-C(3) & $162.4(6)$ & $C(1)-O s(1)-C(2)$ & $94.6(7)$ \\
\hline$C(1)-O s(1)-C(3)$ & $91.4(8)$ & $C(2)-O s(1)-C(3)$ & $97.1(7)$ \\
\hline$C(10)-O s(1)-C(11)$ & $36.9(6)$ & $\mathrm{Os}(1)-\mathrm{Os}(2)-\mathrm{C}(6)$ & $166.1(5)$ \\
\hline $\mathrm{Os}(1)-\mathrm{Os}(2)-\mathrm{C}(11)$ & $47.5(3)$ & $\mathrm{Os}(1)-\mathrm{Os}(2)-\mathrm{C}(12)$ & $78.5(4)$ \\
\hline $\mathrm{Os}(3)-\mathrm{Os}(2)-\mathrm{C}(4)$ & $87.9(4)$ & Os(3)-Os(2)-C(5) & 148.9(6) \\
\hline $\mathrm{Os}(3)-\mathrm{Os}(2)-\mathrm{C}(11)$ & $63.5(4)$ & $\mathrm{Os}(3)-\mathrm{Os}(2)-\mathrm{C}(12)$ & $93.6(3)$ \\
\hline $\mathrm{Os}(3)-\mathrm{Os}(2)-\mathrm{H}$ & $28(5)$ & $C(4)-O s(2)-C(5)$ & $91.4(6)$ \\
\hline$C(4)-O s(2)-C(6)$ & $96.7(7)$ & $C(4)-O s(2)-C(11)$ & $140.9(6)$ \\
\hline$C(4)-O s(2)-C(12)$ & 171.6(6) & $C(5)-O s(2)-C(6)$ & $94.9(8)$ \\
\hline $\mathrm{C}(11)-\mathrm{Os}(2)-\mathrm{C}(12)$ & $35.4(5)$ & $\operatorname{Os}(1)-\operatorname{Os}(3)-\mathrm{C}(9)$ & $154.2(4)$ \\
\hline $\mathrm{Os}(1)-\mathrm{Os}(3)-\mathrm{C}(10)$ & $54.1(4)$ & $\mathrm{Os}(2)-\mathrm{Os}(3)-\mathrm{C}(10)$ & 73.7(4) \\
\hline $\mathrm{Os}(2)-\mathrm{Os}(3)-\mathrm{H}$ & $20(4)$ & $\mathrm{C}(7)-\mathrm{Os}(3)-\mathrm{C}(8)$ & $92.5(7)$ \\
\hline$C(7)-O s(3)-C(9)$ & $95.1(7)$ & $C(7)-O s(3)-C(10)$ & $163.8(6)$ \\
\hline$C(8)-O s(3)-C(9)$ & $95.0(6)$ & $\mathrm{Os}(1)-\mathrm{C}(1)-\mathrm{O}(1)$ & 178(1) \\
\hline $\mathrm{Os}(1)-\mathrm{C}(2)-\mathrm{O}(2)$ & $178(2)$ & $\mathrm{Os}(1)-\mathrm{C}(3)-\mathrm{O}(3)$ & $179(2)$ \\
\hline $\mathrm{Os}(2)-\mathrm{C}(4)-\mathrm{O}(4)$ & 177(1) & $\mathrm{Os}(2)-\mathrm{C}(5)-\mathrm{O}(5)$ & $178(2)$ \\
\hline $\mathrm{Os}(2)-\mathrm{C}(6)-\mathrm{O}(6)$ & 176(1) & $\mathrm{Os}(3)-\mathrm{c}(7)-\mathrm{O}(7)$ & 175(1) \\
\hline $\mathrm{Os}(3)-\mathrm{C}(8)-\mathrm{O}(8)$ & 178(1) & $\mathrm{Os}(3)-\mathrm{C}(9)-\mathrm{O}(9)$ & 177(1) \\
\hline $\mathrm{Os}(3)-\mathrm{C}(10)-\mathrm{C}(23)$ & 133(1) & $C(11)-C(10)-C(23)$ & $118(1)$ \\
\hline$C(10)-C(11)-C(12)$ & 143(1) & $\mathrm{Os}(2)-\mathrm{C}(12)-\mathrm{C}(11)$ & 69.7(8) \\
\hline $\mathrm{Os}(2)-\mathrm{C}(12)-\mathrm{C}(13)$ & $120(1)$ & $C(11)-C(12)-C(13)$ & $122(1)$ \\
\hline$C(16)-C(17)-C(18)$ & $178(2)$ & $C(17)-C(18)-C(19)$ & $177(2)$ \\
\hline $\mathrm{Os}(2)-\mathrm{H}-\mathrm{Os}(3)$ & $130(8)$ & & \\
\hline
\end{tabular}

complex $\mathrm{Os}_{3}(\mathrm{CO})_{10}\left(\mu_{3}-\eta^{2}-\mathrm{C}_{2} \mathrm{Ph}_{2}\right)$ has been illustrated ${ }^{11}$ to exhibit two semibridging $\mathrm{CO}$ ligands but with the two

(29) Collman, J . P.; Hegedus, L. S.; Norton, J . R.; Finke, R. G. Principles and Applications of Organotransition Metal Chemistry; University Science Books: Mill Valley, CA, 1987.

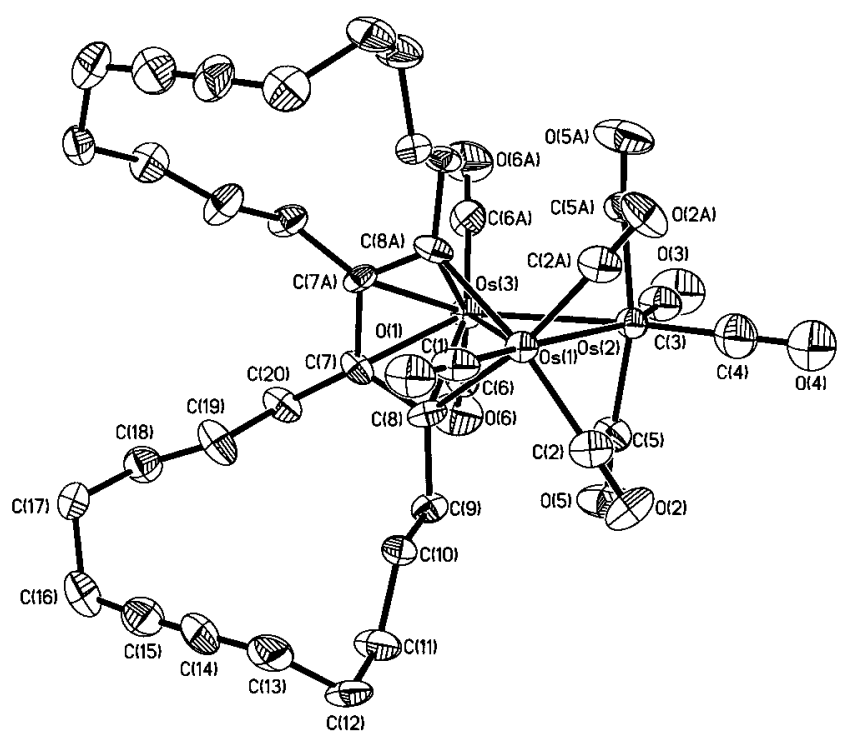

Figure 4. Molecular structure of $\mathrm{Os}_{3}(\mathrm{CO})_{9}\left(\mu-\eta^{4}-\mathrm{C}_{4}\left(\mathrm{C}_{12} \mathrm{H}_{20}\right)_{2}\right)$ (4). The hydrogen atoms have been artificially omitted for darity.

long Os...C distances being roughly equal ( 2.77 and 2.75 $\AA$ ). , In contrast, the analogous 3-hexyne complex $\mathrm{Os}_{3}-$ $(\mathrm{CO})_{10}\left(\mu_{3}-\eta^{2}-\mathrm{C}_{2} \mathrm{Et}_{2}\right)$ displays only one symmetrically bridging $\mathrm{CO}$ ligand.

However, it is noteworthy that the IR spectrum of $\mathbf{2}$ in THF solvent shows a very weak absorption at 1854 $\mathrm{cm}^{-1}$, while its solid-state spectrum in a $\mathrm{KBr}$ disk displays a broad peak at $1840 \mathrm{~cm}^{-1}$ (Figure 1c), characteristic of a bridging $\mathrm{CO}$ ligand. In contrast, the IR spectrum of $\mathrm{Os}_{3}(\mathrm{CO})_{10}\left(\mu_{3}-\eta^{2}-\mathrm{C}_{2} \mathrm{Ph}_{2}\right)$ in the solid state shows no CO absorptions below $1920 \mathrm{~cm}^{-1}$. ${ }^{11,13 \mathrm{~b}}$ It is likely that two energetically comparable structures, with one containing two semibridging $\mathrm{CO}$ ligands as determined and the other containing one bridging $\mathrm{CO}$ ligand as $\mathrm{Os}_{3}(\mathrm{CO})_{10}\left(\mu_{3}-\eta^{2}-\mathrm{C}_{2} \mathrm{Et}_{2}\right)$, are present for $\mathbf{2}$ to account for the IR data, while a single crystal of $\mathbf{2}$ with the former structure was chosen by chance for analysis. We have recently prepared the analogous complex $\mathrm{Os}_{3}-$ $(\mathrm{CO})_{10}\left(\mu_{3}-\eta^{2}-\mathrm{C}_{14} \mathrm{H}_{20}\left(\mathrm{Cp}_{2} \mathrm{Mo}_{2}(\mathrm{CO})_{4}\right)\right)$, the crystal structure of which shows one CO ligand bridging an Os-Os edge. $^{30}$

Crystal Structure of 3. The ORTEP drawing of ( $\mu$ $\mathrm{H}) \mathrm{Os}_{3}(\mathrm{CO})_{9}\left(\mu_{3}-\eta^{3}-\mathrm{C}_{14} \mathrm{H}_{19}\right)$ (3) is shown in Figure 3. Selected bond distances and bond angles are given in Table 3.

The molecule is based on a triangular array of osmium atoms in which the dibridged Os(2)-Os(3) distance of 2.992(1) $\AA$ is significantly longer than the other two intermetallic distances (i.e an Os(1)-Os(3) distance of 2.793(1) $\AA$ and an Os(1)-Os(2) distance of $2.807(1) \AA$ ). E ach osmium atom is associated with three terminal carbonyl ligands. The Os-CO distances range from $1.85(2) \AA(\mathrm{Os}(3)-\mathrm{C}(8))$ through $1.96(2) \AA(\mathrm{Os}(3)-$ $C(7)$ ), while the Os-C-O angles are in the range 175$(1)-179(2)^{\circ}$. The Os(2)-Os(3) edge is bridged by a hydride ligand, which is tilted $19^{\circ}$ out of the triosmium plane away from the allene ligand.

The allene unit $C(10) \sim C(12)$ can be described as forming a $\sigma$ bond to the $\mathrm{Os}(3)$ atom $(\mathrm{Os}(3)-\mathrm{C}(10)=2.05$ -

(30) Hsu, M.-A.; Yeh, W.-Y.; Lee, G.-H.; Peng, S.-M., unpublished results. 
Table 4. Selected Bond Distances $(\AA)$ and Bond Angles (deg) for $\mathrm{Os}_{3}(\mathrm{CO})_{9}\left(\mu-\eta^{4}-\mathrm{C}_{4}\left(\mathrm{C}_{12} \mathrm{H}_{20}\right)_{2}\right)$ (4)

\begin{tabular}{|c|c|c|c|}
\hline \multicolumn{4}{|c|}{ Distances } \\
\hline Os(1)-Os(2) & $2.9286(9)$ & Os(1)-Os(3) & $2.7431(9)$ \\
\hline $\mathrm{Os}(2)-\mathrm{Os}(3)$ & $2.7318(9)$ & $\mathrm{Os}(1)-\mathrm{C}(1)$ & $1.86(2)$ \\
\hline $\mathrm{Os}(1)-\mathrm{C}(2)$ & $1.96(2)$ & $\mathrm{Os}(1)-\mathrm{C}(8)$ & $2.18(1)$ \\
\hline Os(2)-c(3) & $1.87(2)$ & Os(2)-C(4) & $1.82(3)$ \\
\hline Os(2)-C(5) & 1.91(1) & Os(3)-C(6) & $1.86(1)$ \\
\hline Os(3)-c(7) & $2.263(9)$ & Os(3)-C(8) & $2.25(1)$ \\
\hline $\mathrm{C}(1)-\mathrm{O}(1)$ & $1.18(2)$ & $C(2)-O(2)$ & $1.12(2)$ \\
\hline $\mathrm{C}(3)-\mathrm{O}(3)$ & $1.17(2)$ & $\mathrm{C}(4)-\mathrm{O}(4)$ & $1.30(3)$ \\
\hline$C(5)-O(5)$ & $1.15(1)$ & $C(6)-O(6)$ & $1.14(2)$ \\
\hline$C(7)-C(8)$ & $1.40(2)$ & $C(7)-C(7 A)$ & $1.47(2)$ \\
\hline$C(7)-C(20)$ & $1.56(2)$ & $C(8)-C(9)$ & $1.53(1)$ \\
\hline$C(14)-C(15)$ & $1.23(2)$ & & \\
\hline \multicolumn{4}{|c|}{ Angles } \\
\hline $\mathrm{Os}(2)-\mathrm{Os}(1)-\mathrm{Os}(3)$ & $57.47(2)$ & Os(1)-Os(2)-Os(3) & $57.85(2)$ \\
\hline $\mathrm{Os}(1)-\mathrm{Os}(3)-\mathrm{Os}($ & $64.68(3)$ & $\mathrm{C}(1)-\mathrm{Os}(1)-\mathrm{C}(2)$ & $94.9(6)$ \\
\hline$C(2)-O s(1)-C(2 A)$ & $98.2(8)$ & $C(2)-O s(1)-C(8 A)$ & $168.5(4)$ \\
\hline$C(1)-O s(1)-C(8)$ & $88.0(6)$ & $C(2)-O s(1)-C(8)$ & $92.7(5)$ \\
\hline$C(8)-O s(1)-C(8 A)$ & $76.3(5)$ & $C(2)-O s(1)-O s(3)$ & $117.7(4)$ \\
\hline $\mathrm{C}(8)-\mathrm{Os}(1)-\mathrm{Os}(3)$ & $52.8(3)$ & $C(1)-O s(1)-O s(2)$ & $175.3(7)$ \\
\hline $\mathrm{C}(2)-\mathrm{Os}(1)-\mathrm{Os}(2)$ & $82.0(3)$ & $C(8)-O s(1)-O s(2)$ & $95.8(3)$ \\
\hline$C(4)-O s(2)-C(3)$ & $97(1)$ & $C(4)-O s(2)-C(5)$ & 97.1(5) \\
\hline$C(3)-O s(2)-C(5)$ & $90.1(4)$ & $C(5 A)-O s(2)-C(5)$ & $165.8(9)$ \\
\hline $\mathrm{C}(4)-\mathrm{Os}(2)-\mathrm{Os}(3)$ & $162.8(7)$ & $C(3)-O s(2)-O s(3)$ & $100.4(8)$ \\
\hline $\mathrm{C}(5)-\mathrm{Os}(2)-\mathrm{Os}(3)$ & $83.0(4)$ & $C(4)-O s(2)-O s(1)$ & 104.9(7) \\
\hline $\mathrm{C}(3)-\mathrm{Os}(2)-\mathrm{Os}(1)$ & 158.3(8) & $C(5)-O s(2)-O s(1)$ & 87.3(4) \\
\hline$C(6 A)-O s(3)-C(6)$ & 93.2(9) & $C(6 A)-O s(3)-C(8)$ & $161.9(5)$ \\
\hline$C(6)-O s(3)-C(8)$ & $94.6(5)$ & $C(8)-O s(3)-C(8 A)$ & $73.6(5)$ \\
\hline$C(6)-O s(3)-C(7)$ & $97.0(4)$ & $\mathrm{c}(8)-\mathrm{Os}(3)-\mathrm{c}(7)$ & $36.2(4)$ \\
\hline$C(8 A)-O s(3)-C(7)$ & $65.4(4)$ & $C(6)-O s(3)-c(7 A)$ & $126.5(5)$ \\
\hline $\mathrm{C}(6)-\mathrm{Os}(3)-\mathrm{Os}(2)$ & 95.6(4) & $\mathrm{C}(8)-\mathrm{Os}(3)-\mathrm{Os}(2)$ & $99.9(3)$ \\
\hline $\mathrm{C}(7)-\mathrm{Os}(3)-\mathrm{Os}(2)$ & $135.0(3)$ & $C(6)-O s(3)-O s(1)$ & $131.0(5)$ \\
\hline $\mathrm{C}(8)-\mathrm{Os}(3)-\mathrm{Os}(1)$ & $50.7(3)$ & $\mathrm{c}(7)-\mathrm{Os}(3)-\mathrm{Os}(1)$ & $74.6(3)$ \\
\hline $\mathrm{Os}(1)-\mathrm{C}(1)-\mathrm{O}(1)$ & $179(2)$ & $\mathrm{Os}(1)-\mathrm{C}(2)-\mathrm{O}(2)$ & $179(1)$ \\
\hline $\mathrm{Os}(2)-\mathrm{C}(3)-\mathrm{O}(3)$ & $180(2)$ & $\mathrm{Os}(2)-\mathrm{C}(4)-\mathrm{O}(4)$ & $180(2)$ \\
\hline $\mathrm{Os}(2)-\mathrm{C}(5)-\mathrm{O}(5)$ & 175(1) & $\mathrm{Os}(3)-\mathrm{C}(6)-\mathrm{O}(6)$ & 178(1) \\
\hline$C(8)-C(7)-C(7 A)$ & $115.8(6)$ & $C(8)-C(7)-C(20)$ & 124(1) \\
\hline$C(7 A)-C(7)-C(20)$ & $120.5(6)$ & $\mathrm{C}(8)-\mathrm{C}(7)-\mathrm{Os}(3)$ & $71.3(6)$ \\
\hline $\mathrm{C}(7)-\mathrm{C}(8)-\mathrm{C}(9)$ & $123(1)$ & $C(7)-C(8)-O s(1)$ & $115.4(7)$ \\
\hline $\mathrm{C}(9)-\mathrm{C}(8)-\mathrm{Os}(1)$ & $119.0(8)$ & $C(15)-C(14)-C(13)$ & $179(2)$ \\
\hline$C(14)-C(15)-C(16)$ & $176(2)$ & & \\
\hline
\end{tabular}

(1) $\AA$ ) and two $\pi$ bonds from $C(10)=C(11)$ to Os(1) and $\mathrm{C}(11)=\mathrm{C}(12)$ to Os(2) with Os(1)-C $(10)=2.30(1) \AA$, Os$(1)-C(11)=2.10(1) \AA, O s(2)-C(11)=2.27(2) \AA$, and Os$(2)-C(12)=2.34(1) \AA$. The atoms $C(10), C(11), O s(2)$, and Os(3) are coplanar to within $0.05 \AA$ (plane 1). The dihedral angle between plane 1 and the Os(1), Os(2), Os(3) plane is $56.1^{\circ}$, and that between plane 1 and the $\mathrm{C}(11), \mathrm{C}(12), \mathrm{Os}(2)$ plane is $34.0^{\circ}$. The $\mathrm{C}(10)-\mathrm{C}(11)$ and $\mathrm{C}(11)-\mathrm{C}(12)$ distances of $1.41(2)$ and $1.40(2) \AA$ are characteristic of an alkene $\mathrm{C}=\mathrm{C}$ bond $\pi$-coordinated to a transition metal. The uncoordinated alkyne $\mathrm{C}(17)-$ $C(18)$ length is $1.17(2) \AA$.
Crystal Structure of 4. An ORTEP diagram of $\mathrm{Os}_{3-}$ $(\mathrm{CO})_{9}\left(\mu-\eta^{4}-\mathrm{C}_{4}\left(\mathrm{C}_{12} \mathrm{H}_{20}\right)_{2}\right)(4)$ is shown in Figure 4. There are no abnormally short intermolecular contacts. A plane of symmetry is passing through the triosmium framework. Selected bond distances and bond angles are collected in Table 4.

The molecule is formally derived from $\mathrm{Os}_{3}(\mathrm{CO})_{12}$, but with three carbonyls being replaced by a six-electrondonating $\mu-\eta^{4}-\mathrm{C}_{4}\left(\mathrm{C}_{12} \mathrm{H}_{20}\right)_{2}$ ligand (yielding an osmacyclopentadienyl fragment). The Os-Os distances show substantial variation, with $\mathrm{Os}(1)-\mathrm{Os}(2)=2.9286(9) \AA$, $\mathrm{Os}(1)-\mathrm{Os}(3)=2.7431(9) \AA$, and Os(2)-Os(3) = 2.7318(9) $\AA$. The Os(1), Os(2), and Os(3) atoms are each linked to three, four, and two terminal CO ligands, respectively. The average of the Os-CO distances is $1.90 \pm$ $0.08 \AA$, with $\mathrm{C}-\mathrm{O}=1.21 \pm 0.09 \AA$; all Os $-\mathrm{C}-\mathrm{O}$ systems are close to linear $\left(175(1)-180(2)^{\circ}\right)$.

The $\mu-\eta \eta^{4}-\mathrm{C}_{4}\left(\mathrm{C}_{12} \mathrm{H}_{20}\right)_{2}$ ligand forms a $\sigma$-bond to Os(1) $(\mathrm{Os}(1)-\mathrm{C}(8)=2.18(1) \AA$ ) and two $\pi$-bonds to Os(3) (Os$(3)-C(7)=2.263(9) \AA$ and $O s(3)-C(8)=2.25(1) \AA)$. The $C(7), C(7 A), C(8), C(8 A)$, and $O s(1)$ atoms are coplanar to within $0.06 \AA$. The carbon atoms connected to the metallacyclic ring are not eclipsed, as evidenced by the torsional angle $\mathrm{C}(9)-\mathrm{C}(8)-\mathrm{C}(7)-\mathrm{C}(20)=12.8^{\circ}$. The carbon-carbon distances within the metallacycle are $C(7)-C(8)=1.40(2) \AA$ and $C(7)-C(7 A)=1.47(2) \AA$. The uncoordinated alkyne $C(14)-C(15)$ distance is $1.23(2)$ A.

\section{Conclusions}

Several interesting triosmium carbonyl clusters containing cyclotetradeca-1,8-diyne ligands have been prepared and structurally characterized. A unique feature of $\mathbf{1}, \mathbf{3}, \mathbf{4}$, and 5 is their pendant alkyne moieties which are capable of binding other metal fragments, such as $\mathrm{Cp}_{2} \mathrm{Mo}_{2}(\mathrm{CO})_{4}, \mathrm{CO}_{2}(\mathrm{CO})_{6}$, and $\mathrm{Os}_{3}(\mathrm{CO})_{10}$, to form higher nuclearity mixed-metal clusters or cluster oligomers. Further studies aimed at investigating these reactions are in progress.

Acknowledgment. We are grateful for support of this work by the National Science Council of Taiwan.

Supporting Information Available: Complete tables of crystallographic data, positional parameters, anisotropic thermal parameters, bond lengths, and bond angles of 2-4. This material is available free of charge via the Internet at http://pubs.acs.org.

OM980894K 